\title{
Effect of Dietary Energy Concentration on Performance Parameters and Egg Quality of White Leghorn Laying Hens
}

http://dx.doi.org/10.1590/1516-635x1604381-388

\section{-Author(s)}

Ribeiro PAP

Matos Jr JB"

Lara LCIII

Araújo LF'

Albuquerque R

Baião NCIII

VNP/FMVZ Universidade de São Paulo, Pirassununga, Brazil

" DZO FCAV/UNESP Jaboticabal, SP, Brazil

II' DZO/EV Universidade Federal de Minas, Belo Horizonte, Brazil

\section{Mail Address}

Corresponding author e-mail address Pedro de Assunção Pimenta Ribeiro

Av. Duque de Caxias Norte, 225 - Campus da USP - ZIP Code 13635-900 - Pirassununga/SP. Phone: +551935654379

E-mail: pedroribeiro@usp.br

\section{nKeywords}

Energy conversion, egg quality, laying hens.

\section{ABSTRACT}

An experiment was carried out with 1200 23-week-old white Dekalb commercial laying hens to investigate production responses, egg quality, and energy utilization of laying hens fed different dietary energy levels at the beginning of lay. Birds were housed and divided in five groups of 240 birds according to dietary apparent metabolizable energy corrected for nitrogen (AMEn): $2700 \mathrm{kcal} / \mathrm{kg} ; 2775 \mathrm{kcal} / \mathrm{kg}$; $2850 \mathrm{kcal} / \mathrm{kg} ; 2925 \mathrm{kcal} / \mathrm{kg}$; and $3000 \mathrm{kcal} / \mathrm{kg}$, with six replicates of 40 birds each. Birds were fed the experimental diets based on corn and soybean meal for 17 weeks. Diets were iso-nutritive, except for energy level. Increasing AMEn levels had a negative effect on egg production and egg mass $(p \leq 0.05)$. AMEn levels did not influence body weight, egg weight, or livability ( $p>0.05)$. Increasing AMEn levels increased $(p \leq 0.05)$ feed intake and AMEn conversion ratio and feed conversion ratio. AMEn intake remained constant, independently of dietary AMEn level ( $p>0.05)$. There were no differences in albumen height, yolk total solids content, or egg component percentages ( $p>0.05)$. Egg specific weight improved with increasing AMEn levels $(p \leq 0.05)$. Therefore, the energy level of $2700 \mathrm{kcal} / \mathrm{kg}$ of feed may be fed to young laying hens.

\section{INTRODUCTION}

There is a wide variation in the recommendations of energy levels for commercial laying hens among strain management guides and between these guides and tables developed by research institutions, such as the NRC (1994) and the Brazilian Tables for Poultry and Swine (Rostagno et al., 2005). Feeding inadequate energy levels may result in low egg production and body weight, and worse egg quality. The efficiency of energy utilization may also be impaired (Araújo \& Peixoto, 2005).

Wu et al. (2005) observed that feeding increasing AMEn levels to 21-week-old Dekalb White and Bovans White laying hens reduced feed intake in $1 \%$ for each $39 \mathrm{kcal} / \mathrm{kg}$ increase in AMEn dietary levels, and affected egg and yolk weights, but not egg production, egg mass, body weight, or livability. Feed conversion ratio, and consequently, the requirements to produce one gram of egg linearly increased as AMEn increased. Those authors also found effects of AMEn dietary levels on internal and external egg quality, in agreement with their previous findings (Wu et al., 2007). However, Jalal et al. (2006) fed young Hyline W-36 laying hens (21 weeks old) diets with AMEn levels of 2800, 2850 , and $2900 \mathrm{kcal} / \mathrm{kg}$ and did not observe any differences in feed intake, AMEn intake, egg production, body weight, or egg weight.

Jalal et al. (2007) used 22- to 50-week-old white and brown layers (Hy-Line W-36, Hy-Line Brown, Babcock B300, and Shaver White) to two dietary AMEn levels (2810 and $2900 \mathrm{kcal} / \mathrm{kg}$ feed) and the dietary 
supplementation of a commercial enzyme complex to the lowest energy feed, but did not find any differences in body weight, weight gain, feed intake, egg weight, egg production, or egg mass. The only difference found was in AMEn intake, which was the highest for the birds fed the highest energy level. In addition, egg quality parameters, such as specific gravity, eggshell thickness, yolk and albumen percentages, and yolk solids content, were also not influenced by AMEn level, as expected.

The objective of the present study was to evaluate the production performance, egg quality, and energy utilization of young commercial laying hens fed diets containing different AMEn levels, but equal levels of the other dietary nutrients.

\section{MATERIAL AND METHODS}

\section{Bird management}

The experiment was carried out with Dekalb White laying hens between 23 and 40 weeks of age on a commercial farm located in Montes Claros, Minas Gerais, Brazil, located 1653' south and 43.56' west, and at $1080 \mathrm{~m}$ altitude.

In the trial, 1200 layers were housed in $30 \times 45 \mathrm{~cm}$ battery cages with four birds per cage in open-sided layer houses. Each experimental unit consisted of 40 birds, housed in a total of 10 cages, with five cages placed in the upper tier and five in the lower tier for the same replicate. There were six replicates per treatment, totaling 240 birds per replicate. Cages were equipped with manual feeders and nipple drinkers. The average initial weight was $1487 \mathrm{~g}$, and was not different among replicates $(p=0.65$ and $S E M=0.03)$. The experiment was approved by the Ethics Committee for Experimentation in Animals of the Federal University of Minas Gerais under protocol number 08/2008.
Birds were submitted to the following management practices: lighting program of 16 hours of light/day (natural and artificial light). Water and feed were offered ad libitum, and eggs were collected daily.

\section{Dietary treatments}

Dietary nutritional levels were those used by the company, and were calculated considering the feedstuff nutritional concentration of the Brazilian Tables for Poultry and Swine (Rostagno et al., 2005). Feed composition and their calculated nutritional concentration are shown in Table 1.

Treatments consisted of dietary AMEn levels of 2700, 2775, 2850, 2925 and $3000 \mathrm{kcal} / \mathrm{kg}$ feed. All levels of all other nutrients, such as crude protein, amino acids, minerals and vitamins, were the same for all treatments, independently of dietary AMEn level.
Table 1 - Feed composition and calculated nutritional levels

\begin{tabular}{lccccc}
\hline \multirow{2}{*}{ Ingredients } & \multicolumn{5}{c}{ Treatments (kcal/kg feed) } \\
& 2700 & 2775 & 2850 & 2925 & 3000 \\
\hline Corn grain & 60.000 & 64.000 & 64.000 & 63.000 & 61.000 \\
\hline Soybean meal (45\%) & 20.000 & 21.000 & 22.000 & 21.800 & 22.200 \\
\hline Wheat middlings & 7.000 & 2.000 & 0.000 & 0.000 & 0.000 \\
\hline Limestone (<1 mm) & 6.520 & 6.520 & 6.520 & 6.370 & 6.570 \\
\hline Meat and bone meal (45\%) & 4.900 & 4.900 & 4.900 & 4.900 & 4.900 \\
\hline Oyster shell meal (2-3 mm) & 1.000 & 1.000 & 1.000 & 1.000 & 1.000 \\
\hline Salt & 0.280 & 0.280 & 0.280 & 0.280 & 0.280 \\
\hline DL-Methionine & 0.115 & 0.115 & 0.115 & 0.115 & 0.115 \\
\hline Vitamin-mineral supplement ${ }^{1}$ & 0.150 & 0.150 & 0.150 & 0.150 & 0.150 \\
\hline Choline chloride 60\% & 0.035 & 0.035 & 0.035 & 0.035 & 0.035 \\
\hline Soybean oil & 0.000 & 0.000 & 1.000 & 2.350 & 3.750 \\
\hline TOTAL (\%) & 100.00 & 100.00 & 100.00 & 100.00 & 100.00 \\
\hline Calculated nutritional levels & & & & & \\
\hline Linoleic acid (\%) & 1.41 & 1.42 & 1.94 & 2.64 & 3.37 \\
\hline Calcium (\%) & 3.60 & 3.60 & 3.60 & 3.60 & 3.60 \\
\hline Choline (mg/kg) & 1179 & 1175 & 1182 & 1172 & 1174 \\
\hline Available phosphorus (\%) & 0.41 & 0.40 & 0.40 & 0.40 & 0.40 \\
\hline Total phosphorus (\%) & 0.63 & 0.60 & 0.59 & 0.59 & 0.58 \\
\hline Digestible lysine (\%) & 0.76 & 0.77 & 0.78 & 0.78 & 0.78 \\
\hline Dig. methionine + cystine (\%) & 0.61 & 0.61 & 0.61 & 0.61 & 0.61 \\
\hline Digestible methionine (\%) & 0.36 & 0.36 & 0.36 & 0.36 & 0.36 \\
\hline Crude protein (CP) (\%) & 17.3 & 17.3 & 17.3 & 17.3 & 17.3 \\
\hline Sodium (\%) & 0.18 & 0.18 & 0.18 & 0.18 & 0.18 \\
\hline Supp & & & & & \\
\hline
\end{tabular}

${ }^{1}$ Supplied per kilogram of diet: Vitamin supplement: Vit. A 10,000 IU, Vit. D 2,500 IU, Vit E 15 IU, Vit. B, 2 mg, Vit. B, 4 mg, Vit. B 4 mg, Vit. B $15 \mathrm{mg}$, Vit. C $50 \mathrm{mg}$, niacin $30 \mathrm{mg}$, folic acid $0.5 \mathrm{mg}$, pantothenic acid $16 \mathrm{mg}$, biotin $0.06 \mathrm{mg}$, and BHT $125 \mathrm{mg}$. Mineral supplement: manganese $200 \mathrm{mg}$ from manganese oxide, zinc $125 \mathrm{mg}$ from zinc oxide, iron 50 $\mathrm{mg}$ from ferrous sulfate, copper $15 \mathrm{mg}$ from copper sulfate, iodine $1.880 \mathrm{mg}$ ethylene diamine dihydroidide, selenium 0.4 $\mathrm{mg}$ from sodium selenite. 
Because average AMEn levels were determined by the addition of soybean oil and wheat middlings, fiber and fatty acid levels were different among diets, and, according to Oliveira (2009), the inclusion of linoleic acid doe not affect layer performance unless it greater than $1 \%$.

\section{Performance evaluation}

Egg production was daily recorded, and lay percentage calculated based on weekly results. Eggs were weekly weighed to calculate average egg weight. Daily mortality was recorded, and livability was calculated as a percentage of mortality. Egg mass was calculated by multiplying average egg weight by egg production percentage. Feed intake was calculated by subtracting feed residues weight from total feed weight offered during the week.

Daily energy intake was calculated based on the calculated dietary AMEn level content and daily feed intake per bird, and expressed in kcal/bird/day. Similarly, the intake of calcium (Ca), available phosphorus (AvP), crude protein $(C P)$, and digestible sulfur amino acids (digestible methionine + cystine; dSAA) was calculated based on the calculated dietary levels of these nutrients and on feed intake.

Feed conversion ratio was calculated as grams of feed intake/gram of egg produced and by kilograms of feed intake/dozen eggs produced. Energy conversion ratio was determined using feed conversion ratio and dietary AMEn level.

\section{Egg quality parameters}

The egg quality parameters yolk, albumen, and eggshell percentages; total yolk solids; egg specific gravity; Haugh Units (HU); and yolk color were analyzed in five eggs per replicate that were randomly collected every three weeks. Egg specific weight was determined in 30 randomly-chosen eggs per replicate that were laid during in the last three days of every three-week period.

After individually weighed in a digital analytical scale $(0.01 \mathrm{~g}$ precision), eggs were broken, and albumen, yolk, and eggshell were separated. Yolks were individually weighed. Eggshells were washed to remove albumen residues, dried at room temperature for 48h, and then individually weighed. Albumen weight was determined as the difference between intact egg weight minus the sum of yolk and eggshell weights.

Total yolk solids were determined in five replicates of pools of five yolks each. Yolk was weighed, placed in individual containers, and dried in an incubator at $65 \pm 5{ }^{\circ} \mathrm{C}$ for 72 hours, and weighed again. Yolk solids content was calculated as the difference between initial and dry weights (Brasil, 1999).

For $\mathrm{HU}$ analysis, eggs from five replicates of six eggs $(n=30)$ were collected per treatment. Eggs were individually weighed and broken to measure albumen weight using a HU-measuring device (Ames, model S-8400, Massachusetts, USA) (Haugh, 1937).

Egg specific weight was determined in 30 eggs per replicate produced during the last three days of the week, every three weeks, by immersing eggs in graded saline solutions. Egg color was measured using a colorimetric fan (DSM YOLK COLOR FAN, 2005 HMB 51548).

\section{Statistical Analysis}

A completely randomized experimental design, consisting of five treatments with six replicates of 40 birds each, was applied. Data were subjected to analysis of regression using linear and quadratic polynomials (Sampaio, 2007) using SAEG (2005) statistical package. Dietary AMEn level was the independent variable that described the effects on the studied parameters, . All coefficients of the obtained equations were significantly different from zero $(p>0.05)$. Livability data were submitted to square root transformation to obtain normal distribution, but are presented as actual values. As yolk color was subjectively evaluated, the obtained data were submitted to the non-parametric test of Kruskal Wallis, according to the recommendations of Sampaio (2007).

\section{RESULTS AND DISCUSSION}

The effects of dietary AMEn level on the performance parameters are shown in Table 2. Dietary AMEn level influenced feed intake $(p=0.0013)$. The regression analysis indicated that the equation that explains its effect is: $y=-0.033564 X+188.35559\left(r^{2}=0.96\right)$. Most studies in literature also reported reducing feed intake as dietary energy increases (D'Alfonso et al., 1996; Grobas et al. 1999a; Harms et al., 2000; Wu et al., 2005; 2007). According to Wu et al. (2005), feed intake is reduced in $1 \%$ for every $39 \mathrm{kcal} / \mathrm{kg}$ increase, as found in the present study. These results indicate that poultry regulate their feed intake as a function of dietary AMEn level. The energy change required to regulate feed intake were similar to the range used in the present study $(75 \mathrm{kcal} / \mathrm{kg}$ feed), as no statistical differences were detected when all treatments were 
compared. On the other hand, Valkonen et al. (2008) observed increasing feed intake with increasing dietary energy levels; however, the authors used very low AMEn levels (2390 and $2629 \mathrm{kcal} / \mathrm{kg}$ feed), but as feeds contained equal nutrient concentrations, except for energy, feed intake may have been limited by the excessive supply of some other nutrient.

There was no effect of AMEn level on AMEn intake $(p=0.3978 ;$ Table 2). These results were also obtained by Grobas et al. (1999a) and Jalal et al. (2006). The results of the present study are consistent with the findings of Leeson \& Summers (2005), who reported an AMEn intake of $260 \mathrm{kcal} /$ day/bird in 18- to 32-week-old layers. According to Bertechini (1998), commercial laying hens tend to regulate their feed intake as a function of their energy requirement, and therefore, birds with similar production level, body weight, and genetic strain, and submitted to similar management and environmental conditions, tend to regulate their energy intake, independently of feeding regime. Although this is observed in the field and it is supported by literature, some authors obtained different results. For instance, D'Alfonso et al. (1996) found that increasing dietary energy levels reduced energy intake, whereas Harms et al. (2000), Araújo \& Peixoto (2005) and Jalal et al. (2007) reported higher energy intake as dietary AMEn levels increased.

Egg production linearly decreased with increasing AMEn levels $(p=0.0118)$, as shown by the equation $y=-0.0183376 X+141.805\left(r^{2}=0.85\right)$. These results are different from those obtained by other authors (D'Alfonso et al., 1996; Keshavarz, 1998; Grobas et al., 1999a,b; Harms et al., 2000; Costa et al., 2004; Wu et al., 2005, 2007; and Jalal et al., 2006 and 2007), who did not observe any egg production differences in young laying hens fed different AMEn levels. On the other hand, Araújo \& Peixoto (2005) obtained the equation: $y=-251.419079+0.2546842 X-$
$0.00004868 X^{2}$, demonstrating that low AMEn levels increased egg production of laying hens. This is consistent with the findings of Valkonen et al. (2008), who used much lower AMEn levels than those applied in the present study and observed an increase in egg production. Araújo \& Peixoto (2005) used similar AMEn levels as the present study, and also observed a trend of egg production reduction as AMEn level increased. This may be explained by the fact that the diets did not present the same energy levels and that birds reduced their feed intake as AMEn level increased. Therefore, egg production was limited by nutrients, such as amino acids, rather than energy concentration.

There was no effect of AMEn on egg weight $(p=0.1272$; Table 2). This result is consistent with the findings of several authors (Keshavarz, 1998; Grobas et al. 1999a,b; Costa et al., 2004; Araújo \& Peixoto, 2005; Jalal et al., 2006, 2007; Silva et al., 2007; Valkonen et al., 2008), who did not detect any differences in the egg weight of young laying hens fed different AMEn levels. On the other hand, Harms et al. (2000) and Wu et al. (2005; 2007) obtained a positive linear effect of increasing AMEn concentration on egg weight. According to Leeson \& Summers (2005), dietary protein level has a stronger influence on egg weight than energy level itself. As energy levels increased, feed intake was reduced, but amino acid intake was sufficient to maintain similar egg weight in all treatments.

Egg mass was influenced ( $p=0.0084$ ) by AMEn level (Table 2). The regression analysis yielded the equation $y=-0.012928 x+90.124850\left(r^{2}=0.88\right)$. This result is different from those obtained by other authors (D'Alfonso et al., 1996; Keshavarz, 1998; Grobas et al. 1999a,b; Araújo \& Peixoto, 2005; Wu et al., 2005; Jalal et al., 2007; Valkonen et al., 2008), who did not find any influence of dietary AMEn level on egg mass. However, Wu et al. (2007) showed that egg

Table 2 - Effect of dietary energy levels on egg production, egg weight, egg mass, feed intake, AMEn intake, body weight, and livability of young laying hens(23 to 40 weeks of age). **

\begin{tabular}{lccccccccc}
\hline Treatment (kcal/kg) & 2700 & 2775 & 2850 & 2925 & 3000 & Lin & Quad & $\mathrm{r}^{2}$ & SEM \\
\hline Egg production (\%) & 92.86 & 89.90 & 89.35 & 89.36 & 86.25 & $*$ & $\mathrm{~ns}$ & 0.85 & 0.27 \\
Egg weight (g) & 59.64 & 60.12 & 59.11 & 59.52 & 59.09 & $\mathrm{~ns}$ & $\mathrm{~ns}$ & - & 0.11 \\
Egg mass (g egg/bird/day) & 55.38 & 54.05 & 52.81 & 53.19 & 50.96 & $*$ & $\mathrm{~ns}$ & 0.88 & 0.19 \\
Feed intake (g/bird/day) & 97.60 & 95.17 & 92.46 & 91.38 & 86.89 & $*$ & $\mathrm{~ns}$ & 0.96 & 0.28 \\
FCR (g feed/g egg) & 1.76 & 1.76 & 1.75 & 1.71 & 1.70 & $*$ & $\mathrm{~ns}$ & 0.90 & 0.01 \\
FCR (g feed/dz egg) & 1.26 & 1.27 & 1.24 & 1.23 & 1.21 & $*$ & $\mathrm{~ns}$ & 0.87 & 0.01 \\
AMEn conv. (kcal/g egg) & 4.75 & 4.88 & 4.98 & 5.02 & 5.11 & $*$ & $\mathrm{~ns}$ & 0.96 & 0.01 \\
Livability (\%) & 92.91 & 94.86 & 94.16 & 92.91 & 94.58 & $\mathrm{~ns}$ & $\mathrm{~ns}$ & - & 0.76 \\
\hline
\end{tabular}

$*-p \leq 0.05$

ns - not significant: $p>0.05$

** - six replicates per treatment with 40 birds each. 
mass increases as a function of dietary AMEn level. In the present experiment, as egg production decreased with increasing AMEn level and egg weight was not different among treatments, it was expected that egg mass would also decrease as dietary AMEn level increased.

In the beginning of the experiment, bird weight was equalized to an average of $1360 \mathrm{~g}$, and a range of $10 \%$ higher or lower body weight was accepted. Body weight at the end of the experiment was not influenced by dietary AMEn level $(p=0.3571$, Table 2 ). The results of the present study are consistent with other literature reports (D'Alfonso et al., 1996; Keshavarz, 1998; Grobas et al., 1999a and b; Araújo \& Peixoto, 2005; Jalal et al., 2006, 2007; Valkonen et at., 2008). According to Leeson \& Summers (2005), layer live weight hardly changes as a function of diet. In general, weight differences are due to lack of flock uniformity, which is more related to management aspects than to nutritional strategies, because birds of different weights present different nutritional requirements. Bird livability was also not influenced $(p=0.1245)$ by AMEn concentration (Table 2$)$.

Although the experimental feeds contained different energy levels, their nutritional levels were similar, and therefore, macronutrient intake was the same as feed intake. Means and coefficients of regression are shown in Table 3. The regression equation $y=-0.005827 \mathrm{X}+$ 32.69835 represents the effect of dietary AMEn level on crude protein intake $(p=0.0013)$; the equation $y=$ $-0.000205 X+1.149027$ represents the effect of dietary AMEn level on digestible sulfur amino acid intake $(p=0.0013)$; the equation $y=-0.01208 X+6.780673$ represents the effect of dietary AMEn level on calcium intake ( $p=0.0013)$; and the equation $y=-0.000134 X+$ 0.75333 represents the effect of dietary AMEn level on available phosphorus intake $(p=0.0013)$. The $r^{2}$ value obtained for these equations is the same: 0.96.

According to Leeson \& Summers (2005) and Rostagno et al. (2005), feeding programs of laying hens are commonly established as a function of feed intake. However, feed intake is influenced by several factors, such as egg production, bird age, and management and environmental aspects. In addition, laying hens adjust their feed intake by their energy intake (Bertechini, 1998), but there are no evidences that this applies to other nutrients, such as protein. Although energy intake is not a perfect mechanism regulating feed intake in laying birds, feed energy density is a significant limiting factor of feed intake. Because $C P, d S A A, C a$ and AvP concentration were constant in the experimental feeds and feed intake decreased as a function of AMEn level increase, there was an important reduction in the intake of these nutrients. This may partially explain the better performance of the birds fed lower AMEn concentration, possibly because those nutrients were not adequately supplied when higher energy level diets were fed.

Feed conversion ratio was influenced by dietary AMEn level, as shown in Table 3. The analysis of regression yielded the equation $y=-0.000208 X+$ $2.333480\left(r^{2}=0.90\right)$ that represents the effect of AMEn concentration on the feed conversion ratio of young laying hens $(p=0.0068)$. Feed conversion ratio per dozen eggs was also affected, as shown by equation y $=-0.000196 X+1.801573\left(r^{2}=0.87\right)$, indicating a linear improvement of feed conversion ratio per dozen eggs as AMEn concentration increased $(p=0.0095)$.

Feed conversion ratio, calculated both per $\mathrm{kg}$ eggs and per dozen eggs, presented negative linear behavior, that is, feed conversion ratio decreased, and therefore improved as dietary AMEn levels increased. These results are different from those reported by some authors, who did not find any influence of AMEn level on feed conversion ratio (Keshavarz, 1998; Grobas et al., 1999a; Costa et al., 2004), but agree with the findings of others (Grobas et al., 1999b; Wu et al., 2005, 2007; Volknen et al., 2008). The inclusion of soybean oil in energy-rich diets has a positive effect on feed conversion ratio due to its extra-caloric effect

Table 3 - Effect of dietary energy levels on macronutrient intake (CP, dSAA, Ca and AvP), feed conversion ratio ( $\mathrm{g}$ feed/g egg and $\mathrm{g}$ feed/dozen eggs) and AMEn conversion ratio (kcal/g eggs) de young laying hens (23 to 40 weeks)**.

\begin{tabular}{|c|c|c|c|c|c|c|c|c|c|}
\hline Treatment (kcal/kg) & 2700 & 2775 & 2850 & 2925 & 3000 & Lin & Quad & $r^{2}$ & SEM \\
\hline CP intake (g/bird/day) & 16.94 & 16.52 & 15.05 & 15.86 & 15.08 & * & ns & 0.96 & 0.05 \\
\hline dSAA intake (g/bird/day) & 0.59 & 0.58 & 0.56 & 0.56 & 0.53 & * & ns & 0.96 & 0.01 \\
\hline Ca intake (g/bird/day) & 3.51 & 3.43 & 3.33 & 3.29 & 3.12 & * & ns & 0.96 & 0.01 \\
\hline AvP intake (g/bird/day) & 0.39 & 0.38 & 0.37 & 0.36 & 0.35 & * & ns & 0.96 & 0.01 \\
\hline AMEn intake (kcal/bird/day) & 263.48 & 264.09 & 263.51 & 267.30 & 260.67 & ns & ns & - & 0.82 \\
\hline
\end{tabular}

* $-p \leq 0.05$

ns - not significant: $p>0.05$

** - six replicates per treatment with 40 birds each. 
and because it reduces feed passage rate (Bertechini, 1998). Grobas et al. (1999b) mentioned that, in general, the effects of dietary energy level on feed conversion ratio of layers are masked by the use of oils and fats in higher energy diets.

The regression equation indicates that increasing AMEn level negatively affected the efficiency of energy conversion ratio $(p=0.0012$, Table 3$)$. The equation that represents this effect is: $y=0.001141 \mathrm{X}$ $+1.703423\left(r^{2}=0.96\right)$. There are few data available in literature on the energy conversion ratio in layers. Jalal et al. (2006) and Valkonen et al. (2008), working with young layers, did not find any statistical differences in energy conversion ratio. On the other hand, the findings of Araújo \& Peixoto (2005) were consistent with the results of the present study. They determined a negative linear regression equation for the energy conversion ratio of brown laying hens during the initial phase of lay. According to Peguri \& Coon (1991), the efficiency of dietary energy utilization both for weight gain and egg production tends to decrease as dietary energy density increases. When increasing dietary energy level were fed, egg production was reduced, but egg weight and AMEn intake remained constant, probably because the birds fed the higher energy diets consumed excessive energy but the concentration of the other nutrients was low, resulting in worse energy efficiency. Therefore, it is possible to conclude that there is an inverse relationship between feed conversion ratio, which improves with increasing AMEn level probably due to the dietary addition of oils and/or fats, and energy efficiency, which tends to worsen as dietary energy levels increase.

There was a linear reduction of yolk percentage as AMEn concentration increased $(p=0.024)$, as shown by the equation $y=-0.002012 X+29.84753$ (Table 4). Although the $p$ value of this equation was significant, its coefficient of determination was low $\left(r^{2}=0.5565\right)$, rendering the equation estimates unreliable (Sampaio, 2007), possibly because the model does not fit the observed dispersion of the data.

There was no influence of AMEn concentration on albumen percentage $(p=0.2051)$ or on eggshell percentage $(p=0,127)$, as shown in Table 4 . Jalal et al. (2007) and Wu et al. (2007) obtained comparable results with increasing AMEn levels, while Valkonen et al. (2008) observed that laying hens fed low energy diets produced eggs with high yolk percentage and low albumen percentage. According to Bertechini (1998), the ratio among egg components is mainly determined by management factors and bird age, and suffer little influence of nutrition.

Egg specific weight linearly increased with increasing dietary AMEn levels ( $p=0.003$, Table 4$)$. The equation obtained was $y=0.00003 X+1.1081783\left(r^{2}=0.70\right)$. Jalal et al. (2007) and Valkonen et al. (2008) did not find any influence of dietary AMEn level on the specific weight of layer eggs. Despite the statistical difference, the obtained figures are very close. Very low coefficients of variation may indicate significant statistical differences when in fact they do not exist (Sampaio, 2007). Therefore, the studied AMEn levels may not account for any negative effects on the specific weight of young layer eggs. Nevertheless, Wu et al. (2005, 2007) obtained opposite results: increasing AMEn levels reduced egg specific weight, as determined by high egg weight and worse eggshell quality, probably because of lower calcium consumption.

The percentage of yolk solids was not influenced by the evaluated dietary AMEn levels ( $p=0.236$, Table 4). Consistent results were obtained by Oliveira (2009), who fed young layer with different lipid sources, as well as by Jalal et al. (2007) and Wu et al. (2007), when evaluating different dietary energy levels for young laying hens.

Table 4 - Effects of energy levels on egg component percentages, egg specific weight, percentage of yolk solids, Haugh Units, and yolk color of young laying hens (23 to 40 weeks)***.

\begin{tabular}{lccccccccc}
\hline Treatment (kcal/kg) & 2700 & 2775 & 2850 & 2925 & 3000 & Lin & Quad & $\mathrm{r}^{2}$ & SEM \\
\hline Yolk (\%) & 24.60 & 23.90 & 24.27 & 24.01 & 23.79 & $*$ & $\mathrm{~ns}$ & - & 0.90 \\
Albumen (\%) & 66.23 & 66.59 & 66.26 & 66.66 & 66.50 & $\mathrm{~ns}$ & $\mathrm{~ns}$ & - & 0.08 \\
Eggshell (\%) & 10.20 & 10.18 & 10.24 & 10.24 & 10.37 & $\mathrm{~ns}$ & $\mathrm{~ns}$ & - & 0.03 \\
Specific gravity $\left(\mathrm{g} / \mathrm{cm}^{3}\right)$ & 1.0903 & 1.0900 & 1.0904 & 1.0906 & 1.0912 & $*$ & $\mathrm{~ns}$ & 0.70 & 0.01 \\
Yolk solids (\%) & 51.60 & 51.66 & 51.75 & 51.16 & 52.19 & $\mathrm{~ns}$ & $\mathrm{~ns}$ & - & 0.12 \\
Haugh Units & 97.21 & 98.27 & 96.97 & 96.49 & 97.24 & $\mathrm{~ns}$ & $\mathrm{~ns}$ & - & 0.23 \\
Yolk color ** & 6.24 & 6.28 & 6.25 & 6.32 & 6.24 & - & - & - & - \\
\hline
\end{tabular}

$*-p \leq 0.05$

** - Submitted to the Kruskal-Wallis test at $p>0.05$

ns - not significant: $p>0.05$

*** - six replicates per treatment with average of 120 eggs evaluated for specific gravity and 24 for the other parameters. 
There was no effect of AMEn levels HU values of the eggs of young laying hens $(p=0.363$, Table 4$)$. Silva et al. (2007) found a positive quadratic effect in $\mathrm{HU}$ as AMEn intake increased, whereas Wu et al. (2005, 2007) reported a reduction in HU values as AMEn concentration increased.

There was no influence of dietary AMEn concentration on yolk color ( $p>0.05$, Table 4). This result is consistent with the findings of $\mathrm{Wu}$ et al. (2007), who did not detect any effects of AMEn levels on yolk color, whereas Silva et al. (2007) found higher yolk color values in the eggs of laying hens fed diets with higher oil content.

\section{CONCLUSIONS}

Egg production linearly decreased as energy levels increased from 2700 to $3000 \mathrm{kcal} / \mathrm{kg}$ of feed, whereas energy intake and egg weight were not affected by dietary energy levels. Because this effect is linear, further studies should be performed using dietary lower energy levels. Energy levels of $2700 \mathrm{kcal} / \mathrm{kg}$ of feed may be fed to young laying hens.

\section{REFERENCES}

Araújo J, Peixoto RR. Níveis de energia metabolizável em rações para poedeiras de ovos marrons nas condições de inverno no extremo sul do brasil. Archivos Zootecnia 2005;54:13-23.

Bertechini AG. Nutrição de monogástricos. Lavras: UFLA,FAEPE; 1998

Brasil. Ministério da Agricultura. Secretaria Nacional de Defesa Agropecuária. Laboratório Nacional de Referência Animal. Métodos analíticos oficiais para controle de produtos de origem animal e seus ingredientes: métodos físicos e químicos. Brasília, DF; 1999. v.2.

Costa FGP, Souza HC, Gomes CAV, Barros LR, Brandão PA, Nascimento GAJ, Santos AWR., Amarante Júnior, V S. Níveis de proteína bruta e energia metabolizável na produção e qualidade dos ovos de poedeiras da linhagem Lohmann Brown. Ciência Agrotécnica 2004;28:14211427

D'Alfonso TH, Manbeck HB, Roush WB. Effect of day to day variation of dietery energy on residual feed intake of laying hens. Poultry Science 1996;75:362-369.

Grobas S, Mendez J, De Blas C, Mateos GG. Influence of dietary energy, supplemental fat and linoleic acid concentration on performance of laying hens at two ages. British Poultry Science 1999a; 40: 681-687.
Grobas S, Méndez J, Blas C, Mateos GG. Laying hen productivity as affected by energy, supplemental fat, and linoleic acid concentration of the diet. Poultry Science 1999b;78:1542-1551.

Harms RH, Russell GB, Sloan RR. Performance of four strains of commercial laying hens with major changes in dietary energy. Journal of Applied Poultry Research 2000;9:535-541.

Haugh RR. The Haugh unit for measuring egg quality. United States Egg Poultry Magazine 1937; 43:552-555.

Jalal MA, Scheideler SE, Marx D. Effect of bird cage space and dietary metabolizable energy level on production parameters in laying hens. Poultry Science 2006;8:5306-311.

Jalal MA, Scheideler SE, Pierson EM. Strain response of laying hens to varying dietary energy levels with and without avizyme supplementation. Journal of Applied Poultry Research 2007;16:289-295.

Keshavarz K. The effect of light regimen, floor space, and energy and proteins levels during the growing period on body weight and early egg size. Poultry Science 1998;77:1266-1279.

Leeson S, Summers JD. Commercial poultry nutrition. Guelph: University Books; 2005. 398p.

National Research Council. Nutrient requirements of poultry. $9^{\text {th }}$ rev. ed. Washington, DC: Natl. Acad. Press; 1994.

Oliveira DD. Fontes de lipídios na dieta de poedeiras: efeito sobre a produção e o perfil de ácidos graxos na gema [dissertação]. Belo Horizonte: Escola de Veterinária da UFMG; 2009.

Peguri A, Coon CN. Effect of temperature and dietary energy on layer performance. Poultry Science 1991;70:126-138.

Rostagno HS, Albino LFT, Donzele JL, et al. Tabelas brasileiras para aves e suínos - composição de alimentos e exigências nutricionais. Viçosa: UFV; 2005.

Sampaio, I.B.M. Estatística aplicada à experimentação animal. $3^{a}$ ed. Belo Horizonte: FEPMVZ; 2007

Silva ABP, Burini RC, Silva EMP, Garcia EA, Pizzolante CC, Saldanha ESPB Deodato AP, Molino AB. Efeito do consumo de energia e óleo vegetal sobre a qualidade de ovos de poedeiras semipesadas. Ciência Animal Brasileira 2007;8:647-656.

Saeg. Sistema para análise estatística e genética. Versão 9.1. [CD-ROM]. Viçosa: Universidade Federal de Viçosa; 2005.

Valkonen E, Venalainen E, Rossow L, Valaja J. Effects of dietary energy content on the performance of laying hens in furnished and conventional cages. Poultry Science 2008;87:844-852.

Wu G, Bryant MM, Gunawardana P, Roland Sr DA. Effect of nutrient density on performance, egg components, egg solids, egg quality, and profits in eight commercial leghorn strain during phase one. Poultry Science 2007;86:691-697.

Wu G, Bryant MM, Voitle RA, Roland DA. Effect of dietary energy on performance and egg composition of Bovans White and Dekalb White hens during phase I. Poultry Science 2005;84:1610-1615. 
